\title{
RECENT TAXONOMIC NOTES AND NEW DISTRIBUTION LOCALITIES OF PODOCARPUS PERS. SPECIES IN THE PHILIPPINES
}

\author{
Florence Roy P. Salvaña ${ }^{1}$, William Sm. Gruezo ${ }^{2}$ \& Annalee S. Hadsall ${ }^{3}$
}

\begin{abstract}
A B S TR ACT
The taxonomy of plants provides a great contribution to understanding diversity and conservation. This study provides additional taxonomic notes on Podocarpus species in the Philippines using newly collected specimens to determine new distribution localities of these species. This study recognises ten species of Podocarpus in the Philippines. Notable results of this study are: (1) the existence of variable leaf forms in P. pilgeri Foxw. correlated to the type of habitat where the species occurs; (2) variable leaf forms and sizes observed in mature and juvenile leaves of all species; (3) support of the sectional arrangement of P. palawanensis de Laub. \& Silba; (4) differences between the wild and cultivated representatives of $P$. costalis C.Presl based on leaf characters; (5) new distributions for $P$. ramosii R.R.Mill, P. pilgeri, P. costalis, P. neriifolius D.Don, P. rumphii Blume and $P$. polystachyus R.Br.; (5) no support for the inclusion of $P$. neglectus Blume and $P$. hookeri de Laub. as new species found in the Philippines; and (6) comprehensive examination and identification of numerous herbarium specimens and recently collected material.
\end{abstract}

\section{INTRODUCTION}

In the Philippines, the first formal assessment of conifers, including 11 species of Podocarpus, was carried out by Foxworthy (1911) although some species were enumerated by Merrill (1923). After several decades, another assessment was made by de Laubenfels (1978) who recognised nine species of Podocarpus. Some of the species identified in the first assessment were synonymised since they were regarded as problematic. However, in the same paper de Laubenfels (1978) described three new species, Podocarpus rotundus de Laub., P. lophatus de Laub. and P. macrocarpus de Laub., the last two of which are endemic to the Philippines. Later, de Laubenfels \& Silba (1988) added a fourth new Podocarpus species to the Philippine flora, P. palawanensis de Laub. \& Silba. In the recent revision made by de Laubenfels (2015), two species were added including Podocarpus hookeri de Laub. and Podocarpus neglectus de Laub. With the addition of P. hookeri, Podocarpus section Acuminatus was also added to the sections of this genus recorded from the Philippines. In addition, there was sectional rearrangement for $P$. costalis and $P$. lophatus from section Macrostachyus to section

1. Florence Roy P. Salvaña is an Instructor in the Department of Biological Sciences, University of Southern Mindanao. Address: College of Arts and Sciences, University of Southern Mindanao, Kabacan 9407, Cotabato, Philippines. Email: rdsalvana@usm.edu.ph 2. William Sm. Gruezo is a Professor in the Plant Biology Division, University of the Philippines Los Baños, College, Laguna.

Email: asialifesciences@yahoo.com

3. Annalee S. Hadsall is an Assistant Professor in the Plant Biology Division, and Curator of the Botanical Herbarium, UPLB Museum of Natural History, University of the Philippines Los Baños, College, Laguna.

Email: ashadsall@up.edu.ph 
Spathoides. A total of 12 species of Podocarpus were accounted for in the Philippines by de Laubenfels (2015), however only ten are recognised in this study.

As noted by de Laubenfels (1985), Podocarpus is one of the plant groups that needs further investigation and delimitation in terms of an important number of species. While Podocarpus in other parts of the world have been studied by various people, since 1978 little research has focused on reassessing the taxonomic status of the members of this genus in the Philippines. The most recent revision, with an emphasis on species found in the Malesian region, was done by de Laubenfels (1988) with a minimal number of specimens examined especially for Philippine representatives. Thus, reassessment is needed to construct a more complete key to the species in the Philippines through examination of newly collected specimens from different sampling sites. Reassessment also provides a new range of measurements of important plant parts and new descriptions since some of the characters used in the previous revisions were not conclusive. Moreover, new distribution maps for each species are included in this study.

\section{MATERIALS AND METHODS}

Field studies were carried out and samples collected at selected sites where species of Podocarpus were found. The overall characteristic of the habit of each species was noted. A collection number was placed in each of the samples collected. Important data including locality, site description, habitat, date, etc. were recorded. On-site pre-identification and photo documentation of each sample collected were carried out.

Each of the samples collected was examined. The morphology of both vegetative and reproductive structures, such as leaf shape, margin, apex and base, male cones and seed-bearing structures, was characterised. Foliage buds and scales were also examined. Measurements such as leaf length and width, and male and female cone length and diameter were taken using calipers. All of these characters were used in the construction of a dichotomous key.

Materials of Philippine Podocarpus deposited in Philippine herbaria were examined. These herbaria include (1) Botanical Herbarium (CAHUP), Museum of Natural History, University of the Philippines Los Baños, College, Laguna; (2) Philippine National Herbarium (PNH), National Museum, Manila; and (3) Jose Vera Santos Memorial Herbarium (PUH), Institute of Biology, University of the Philippines Diliman, Quezon City. Digital collections from international herbaria were also used as additional references.

\section{RESULTS AND DISCUSSION}

Key to Philippine sections of Podocarpus

1. Pollen cones elongating on a basal scaly part, $1-10 \mathrm{~mm}$ long; receptacle fertile bracts as small as $5 \mathrm{~mm}$ long; leaves oval to long-elliptic......... Podocarpus sect. Gracilis 
1. Pollen cones sessile; receptacle fertile bracts up to $15 \mathrm{~mm}$ long; leaves linear to linear-

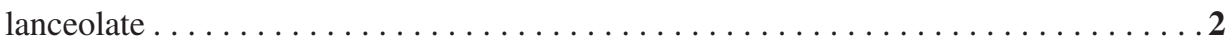

2. Foliage bud scales imbricate ..............Podocarpus sect. Rumphii

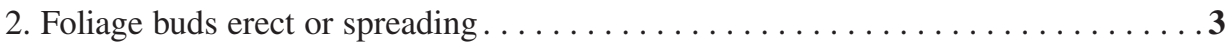

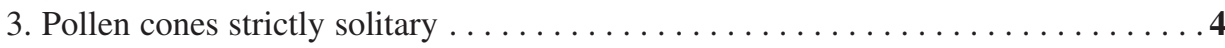

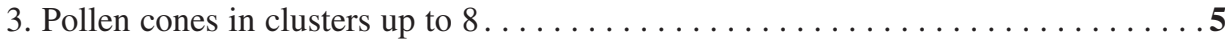

4. Microsporophyll apex lanceolate. ...........Podocarpus sect. Macrostachyus

4. Microsporophyll apex elongated triangular or rounded .......... Podocarpus

sect. Spathoides

5. Leaf upper midrib raised or blunt with nearly vertical sides . . . . . . Podocarpus sect. Foliolatus

5. Leaf upper midrib broad and blunt with more or less sloping sides. . . . Podocarpus sect. Polystachyus

The ten recognised species of Podocarpus in the Philippines belong to six sections. Three out of the 12 species belong to section Gracilis including Podocarpus ramosii, $P$. pilgeri and P. glaucus. Podocarpus lophatus and P. costalis are species transferred to section Spathoides (de Laubenfels, 2015) due to oblong leaves with blunt apices and broad and robust pollen cones, respectively. De Laubenfels (2015) rearranged the sections containing these species. In previous revisions, P. lophatus belonged to section Gracilis and P. costalis belonged to section Macrostachyus. Podocarpus polystachyus and P. macrocarpus belong to section Polystachyus. Sections Foliolatus, Rumphii and Macrostachyus are represented by one species each, $P$. neriifolius, $P$. rumphii and P. palawanensis respectively.

Key to Philippine species of Podocarpus

1. Mature leaves short, less than $8 \mathrm{~cm}$; leaf margin slightly revolute $\ldots \ldots \ldots \ldots \ldots 2$

1. Mature leaves long, more than $8 \mathrm{~cm}$, up to $26 \mathrm{~cm}$; leaf margin not revolute . . . .6

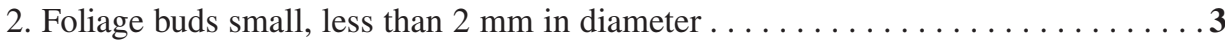

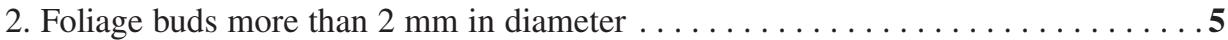

3. Leaves spreading or scattered; seeds without distinct crest $\ldots \ldots \ldots \ldots \ldots \ldots$

3. Leaves crowded; seeds with distinct crest......... 1. Podocarpus glaucus (Fig. 1)

4. Mature leaves oval with rounded apex; male cone basal scaly structure more than $3 \mathrm{~mm} \ldots \ldots \ldots \ldots \ldots \ldots \ldots \ldots \ldots \ldots \ldots \ldots \ldots \ldots$. Podocarpus ramosii (Fig. 2)

4. Mature leaves ovate, widest part near apex, with acute apex; male cone basal scaly structure less than $3 \mathrm{~mm}$.................... Podocarpus pilgeri (Fig. 3)

5. Leaves densely crowded, leathery, long elliptic; foliage buds with lanceolate scales slightly spreading; male cones short, up to $3 \mathrm{~cm}$ long with apex of the microsporophyll

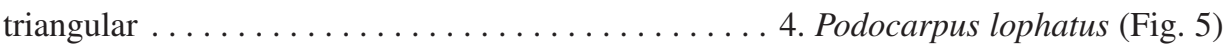

5. Leaves scattered, smooth, linear to linear lanceolate; foliage buds with triangular scales spreading at the apex; male cones up to $4.5 \mathrm{~cm}$ long, with apex of the microsporophyll either lanceolate or elongate-triangular.... 5. Podocarpus costalis (Fig. 6) 
6. Upper midvein raised, sharp, narrow with perpendicular sides; leaves abruptly tapered

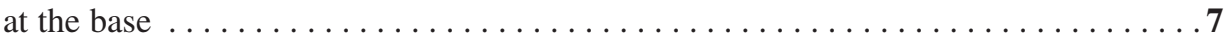
6. Upper midvein nearly flat, dull, broad with sloping sides; leaves gradually tapered at

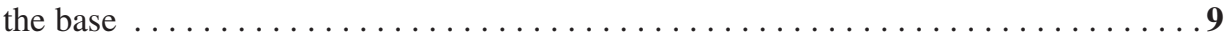

7. Foliage bud scales spreading mostly at the apical portion; leaf length up to $19 \mathrm{~cm} . \mathbf{8}$ 7. Foliage bud scales not spreading; leaf length up to $26 \mathrm{~cm} \ldots \ldots \ldots$. . Podocarpus rumphii (Fig. 8)

8. Male cones solitary, in a peduncle, $4.5 \mathrm{~cm}$ long ..... . 7. Podocarpus palawanensis

(Fig. 9)

8. Male cones in clusters of commonly three, sessile.....8. Podocarpus neriifolius

(Fig. 11)

9. Seed up to $15 \mathrm{~mm}$ long, $10 \mathrm{~mm}$ in diameter; male cones clustered in groups of four. . . . . . . . . . . . . . . . . . Podocarpus macrocarpus (Fig. 13) 9. Seed $8 \mathrm{~mm}$ long, $5 \mathrm{~mm}$ in diameter; male cones not clustered in groups of four. . . . . . . . . . . . . . . . 14)

1. Podocarpus glaucus Foxw., Philipp. J. Sci., C. 2 (1907) Bot. 258; ibid. 6 (1911) Bot. 159, t. 29 f. 1; Pilger in Engler \& Prantl, Nat. Pflanzenfam., ed. 2, 13 (1926) 248; Wasscher, Blumea 4 (1942) 468; N.E. Gray, J. Arnold Arbor. 39 (1958) 440; Gaussen, Gymn. Act. \& Foss. Fasc. 14, ch. 21 (1976) 163, t. 825; de Laubenfels, Kalikasan 7 (1978) 138; Fl. Males., Ser. 1, Spermat. 10 (1988) 411. TYPE: Luzon, Mindoro, Mt Halcon, 1906, Merrill 5672 (K, NY, US isotypes).

A decumbent shrub to small tree, up to $15 \mathrm{~m}$ tall and $25 \mathrm{~cm}$ dbh. Foliage buds small, $1-1.5 \mathrm{~mm}$ long and $1.2-1.5 \mathrm{~mm}$ in diameter, slightly spreading scales. Leaves crowded especially terminal part of the branches, long elliptic to oblong, rounded to obtuse, slightly revolute; varying in size, leaves from saplings larger, 2-4 cm long and 6-7 mm wide, oblong, glaucous flushing red near the margin; adult leaves $0.9-2 \mathrm{~cm}$ long and 3-5.5 mm wide, ovate, rounded and blunt apex; shaded leaves, c. $1 \mathrm{~cm}$ long and 3-4 mm wide; exposed leaves, $1-1.5 \mathrm{~cm}$ long and 2.5-4 mm wide; upper midvein distinguished by a narrow rib $0.2-0.3 \mathrm{~mm}$ and broadly and indistinct below, tapered at the base to a 1.5-2 mm petiole. Male cones slender, 1-2 $\mathrm{cm}$ and 2.5-3 mm including sterile basal scales, the latter 1-2 mm, forming a cluster, microsporophyll apex triangular. Foliola 1-1.5 mm long. Seed-bearing structure pedunculate, the peduncle 3-4 $\mathrm{mm}$ long; receptacle with fertile bract 6-8 $\mathrm{mm}$ long, with spreading apex and shorter sterile bract; seed globose, including its covering 8-10 $\mathrm{mm}$ long and 5-6 $\mathrm{mm}$ in diameter, with a distinct crest.

Etymology The specific epithet refers to the glaucous younger leaves. Not all leaves of this species are coloured.

In the Philippines, the species is known only in Mt Halcon, Mindoro. Some of the measurements added in this work are based on the new collections deposited in CAHUP and PUH. The crowded arrangement of the leaves separates the species from P. pilgeri (Fig. 3). 
Material examined:

LUZON. Mindoro, Mt Halcon, Cajano \& Realista 62516, 62515, 62514 (CAHUP!), Merrill 9427 (PUH!), Merrill 5672 (K!, US!, NY!).

2. Podocarpus ramosii R.R. Mill, Edinburgh J. Bot. 63 (2006) 81. Podocarpus rotundus de Laubenfels, Kalikasan 7(2): 136. 1978, nom. illegit., non Bocharn. (1960); Fl. Males., Ser. 1, Spermat. 10 (1988) 411. TYPE: Luzon, Tayabas Prov., 1913, Ramos 19581 (holotype US, isotypes $\mathrm{K}, \mathrm{L}, \mathrm{BM}$ )

A small to medium-sized tree 5-15 $\mathrm{m}$ tall and $20 \mathrm{~cm}$ dbh. Foliage buds small, $2.4-3 \mathrm{~mm}$ long and 1.6-2 $\mathrm{mm}$ in diameter, scales slightly spreading. Leaves scattered, oval, apex rounded; varies in size, leaves from saplings, 5- $6.8 \mathrm{~cm}$ long and 8-9 mm wide, slightly linear; adult leaves, $1-6.7 \mathrm{~cm}$ long and 7-11 mm wide, oval to slightly linear; shaded leaves, 5-8 cm long and 12-13 mm long; exposed leaves, 1-2.6 cm long and 5-6 mm wide, very rounded apex; upper midvein distinguished by a narrow rib $0.2-0.3 \mathrm{~mm}$ and broadly and indistinct below, tapered at the base to a $1-3 \mathrm{~mm}$ petiole. Male cones slender, $2.5-3.5 \mathrm{~cm}$ long and $3 \mathrm{~mm}$ in diameter including sterile basal scales, 1-3 $\mathrm{mm}$ long, microsporophyll apex triangular. Foliola 1.5-2 mm long. Seed-bearing structure on a peduncle, 4-11 mm; receptacle with fertile bract 5-7 mm and shorter sterile bract; seed globose with its covering, 7-8 $\mathrm{mm}$ long and 5.5-6 $\mathrm{mm}$ in diameter, without crest.

Etymology This species is named after Maximo Ramos who made extensive collections of the Philippine flora.

The new name of the species was provided by Mill (2006). Podocarpus rotundus de Laub. was found to be illegitimate because of the earlier homonym Podocarpus rotundus Bocharn. (1960), a fossil species from Russia (Mill, 2002). Newly collected specimens from Mt Banahaw, Mt Isarog and Bicol National Park revealed different measurement ranges of some essential parts such as the juvenile and mature leaves and those taken from exposed and shaded parts. This species also closely resembles $P$. costalis; however, they are distinct in the structure of the pollen cones and occupy different habitats. One specimen collected from Mt Halcon named as $P$. ramosii has been re-determined to $P$. pilgeri. New distribution areas for the species include Mt Isarog National Park and Bicol National Park, Camarines Province (Fig. 4).

Material examined:

LUZON, Quezon Province, Mt Banahaw, Fernando 55 (CAHUP!, LBC!), Gruezo 5764 (CAHUP!), Hernaez 3677, 3518 (CAHUP!), Co 2124 (PUH!), Gates 246 (CAHUP!), Gates \& Santos 6151 (CAHUP!), de Laubenfels P663 (CAHUP!, L!), P664 (CAHUP!), P665 (L!, CAHUP!), Ramos 19581 (K!, L!), Loher 2140 (K). Tayabas, Lucban Elmer 7778 (L!). Camarines Sur, Bicol National Park, Cajano \& Hernaez 57335 (CAHUP!). Mt Isarog National Park, Balete 15 (CAHUP!).

3. Podocarpus pilgeri Foxw., Philipp. J. Sci. C 2 (1907) 259; 6 (1911) 160; Pilger, Bot. Jahrb. Syst. 54 (1916) 38; in Engler \& Prantl, Nat. Pflanzenfam., ed. 2, 13 (1926) 248; 
N.E. Gray, J. Arnold. Arbor. 39 (1958) 459; Gaussen, Gymn. Act. \& Foss. Fasc. 14, ch. 21 (1976) 185, t. 810; de Laub., Kalikasan 7 (1978) 135; Fl. Males., Ser. 1, Spermat. 10 (1988) 410. TYPE: Luzon, Mindoro, Mt Halcon, 1906, Merrill 5754 (K, NY isotypes).

Podocarpus schlechteri Pilg., Bot. Jahrb. Syst. 54 (1916) 209. TYPE: Papua New Guinea, 1908, Schlechter 18780 (BR, isotype), 1913, Ledermann 12755 (K, syntype).

Podocarpus wangii Chang, Sunyatsenia 6 (1941) 26. TYPE: China, 1936, Wang 40106 (A, isotype).

A small tree 1-5 m tall, occasionally to $25 \mathrm{~m}$ tall. Foliage buds small, 2.5-4 mm long and 2-3 $\mathrm{mm}$ in diameter, slightly spreading lanceolate scales. Leaves scattered, varying in size; leaves from saplings larger, 2.5-7 cm long and 5-9 mm wide, linear, acute, sometimes apiculate, flushing red when young; adult leaves, $1.5-3 \mathrm{~cm}$ long and 5-7 mm wide, ovate, widest part near apex; shaded leaves, $2.5-4 \mathrm{~cm}$ long and 6-8 $\mathrm{mm}$ wide, abruptly rounded apex; exposed leaves, $2-4 \mathrm{~cm}$ long and $4.5-6 \mathrm{~mm}$ wide, linear to elliptic, acute, slightly revolute; upper midvein distinguished by a narrow rib $0.2-0.4 \mathrm{~mm}$ and broadly and approximately indistinct below, gradually tapered at the base to a 2-5 $\mathrm{mm}$ petiole. Male cones slender, $2.5-3 \mathrm{~cm}$ long and $3 \mathrm{~mm}$ in diameter, including sterile basal scales forming a cluster, microsporophyll apex triangular. Foliola 1.5-2 mm long. Seed-bearing structure on a peduncle up to $8-10 \mathrm{~mm}$; receptacle with fertile bract, equal to the length of the peduncle, and shorter sterile bract; seed globose, including its covering $8-10 \mathrm{~mm}$ long and 6-7 $\mathrm{mm}$ in diameter, without a crest.

Etymology The species is named after Robert Pilger, a German botanist who greatly contributed to gymnosperm taxonomy.

Ovate, linear, linear-lanceolate and elliptic were some of the observed leaf forms of P. pilgeri. Specimens with linear and linear-lanceolate leaves occurred at higher elevation and with less canopy cover while most specimens with ovate and elliptic leaves are collected from lower altitudes and with greater canopy cover. Different measurement ranges of the essential parts are added in this work based on the newly collected samples. Species distribution is localised in the southern part of the Philippines, but one population is recorded on Mt Halcon, Mindoro. One specimen deposited in CAHUP is named $P$. brevifolius. This is $P$. pilgeri since $P$. brevifolius is not found in the Philippines but is restricted to Mt Kinabalu in Sabah. The characteristics of the leaves also reflect $P$. pilgeri. Two distribution records are added for the species, Lupiagan and Bukidnon. These are part of the Mt Kitanglad range and Davao City, part of the Mt Apo Range (Fig. 4).

Material examined:

LUZON. Mindoro, Mt Halcon, Merrill 5754 (K!, NY!), Mandia 390 (K!), Merrill 5615 (US!). VISAYAS. Negros, Mt Canlaon, Edaño 22015 (PNH!, L!), Merrill 241 (U!, US!). MINDANAO. Davao, Mt McKinley, Edaño 985 (L!), 4921 (PUH!). Bukidnon, Mt Kitanglad, Madulid et al. PPI3149 (K!), Sulit 10056, 10135 (L!, PNH!), Ramos \& Edaño BS38500 (L!, K!). Mt Dulang-Dulang, Malaybalay Cajano \& Hernaez 60617 (CAHUP!). Agusan del Norte, Cabadbaran, Elmer 14086 (L!, U!, K!). Misamis Oriental, Mt Malindang, Hutchinson PFB4673 (L!, K!). 
4. Podocarpus lophatus de Laub., Kalikasan 7, 2 (1978) 137; Fl. Males., Ser. 1, Spermat. 10 (1988) 411. De Laub., Novon, 24 (2015) 150. TYPE: Luzon, Zambales, Mt Tapulao, 1907, Curran \& Merritt 9511 (US, holotype, BO, K, NY, P, isotypes).

A shrub to small tree 3-10 m tall. Foliage buds small, 2-3 mm long and 2-2.3 $\mathrm{mm}$ in diameter, with lanceolate scales spreading mostly at the apex. Leaves densely crowded, elliptic, acute, varying in size, leaves from saplings larger, $3.5-4.6 \mathrm{~cm}$ long and 5-7 mm wide, with red flush especially near the margin, slightly revolute; adult leaves, $3-4 \mathrm{~cm}$ long and 5-6 mm wide, elliptic to slightly linear; upper midvein broad and low, 0.2-0.3 $\mathrm{mm}$ above and broadly and approximately indistinct below, tapered at the base to a 1.5-2 $\mathrm{mm}$ petiole. Male cones robust, $2-4 \mathrm{~cm}$ long and $7-8 \mathrm{~mm}$ in diameter including sterile basal scales forming a cluster, microsporophyll apex triangular. Foliola, $1.5 \mathrm{~mm}$ long. Seed-bearing structure pedunculate, up to 4-6 mm long; receptacle with fertile bract 4.5-6 mm long and shorter sterile bract; seed globose, including its covering 6-7 mm long and 4-5 $\mathrm{mm}$ in diameter, tapered at the apex to a distinct crest.

Etymology The species name lophatus comes from the Greek and means crested. Seed crest is one unique feature of this species.

We here give the first description and illustrations of the previously unknown male cones of $P$. lophatus. They are cylindrical with a basal scaly structure and triangular microsporophyll apex. The species is known to be endemic in Mt Tapulao, Zambales (Fig. 7). One specimen collected from Mt Halcon, Mindoro (Mandia, 390 (K)) had been named $P$. lophatus, however the specimen is P. pilgeri. Moreover, specimens collected from Mt Banahaw, Quezon are also named P. lophatus as cited from Gascon et al. (2013), however these are $P$. ramosii with a more or less acute apex which is one variable form of the species. Variable forms of the leaf also occur in this species. In this work, these variations are observed in the juvenile and mature leaves which are reflected in the description.

Material examined:

LUZON. Zambales, Mt Tapulao, Ferreras 16663 (PUH!); Curran \& Merritt 9511 (NY!, K!)

5. Podocarpus costalis C.Presl, Epimel. Bot. (1851) 236; Pilger, Pflanzenr IV, 5, Heft 18 (1903) 78; Foxw. Philipp. J. Sci. C 6 (1911) Bot. 161, p.p.; N.E. Gray, J. Arnold. Arbor. 39 (1958) 456; Gaussen, Gymn. Act. \& Foss. Fasc. 14, ch. 21 (1976) 183, t. 831; Fl. Males., Ser. 1, Spermat. 10 (1988) 414. De Laub., Novon, 24 (2015) 150. Nageia costalis Kuntze, Revis. Gen. Pl. 2 (1891) 800. TYPE: Luzon, 1792, T. Haenke s.n. (PR, holotype).

A small to medium-sized tree up to $8 \mathrm{~m}$ tall and $20 \mathrm{~cm}$ dbh. Foliage buds $2-4 \mathrm{~mm}$ long and 2-3 in diameter, with long triangular scales spreading at the apex. Leaves more or less linear, sometimes spatulate, rounded, slightly revolute, short and broad or long or narrow; varies in size, leaves from saplings larger, up to $7 \mathrm{~cm}$ long and 1.5-4 $\mathrm{mm}$ wide, acute or rounded apex; adult leaves $2.5-7 \mathrm{~cm}$ long and 5-11 $\mathrm{mm}$ wide, broadly acute or rounded at the apex; upper midvein distinguished by a distinct rib $0.2-0.4 \mathrm{~mm}$ 
with sloping sides and less distinct below, tapered more or less abruptly at the base to a 2-4 mm petiole. Male cones robust, sessile and solitary, 3-4 cm long and 5-7 $\mathrm{mm}$ in diameter including the base with small membranous scales, 1-2 mm long, microsporophyll apex triangular and sometimes elongate and rounded. Foliola, 1-1.5 mm long, falling early. Seed-bearing structure on a peduncle, $4-5 \mathrm{~mm}$ long; receptacle with fertile bract $8-14 \mathrm{~mm}$ long and several $\mathrm{mm}$ shorter sterile bract; seed globose with its covering, 7-10 $\mathrm{mm}$ long and 6-7 $\mathrm{mm}$ in diameter and a small crest.

Etymology The specific epithet refers to the rib on the leaf.

This species is transferred into section Spathoides due to its leaves with blunt and broad apices. The species is known to be popular in cultivation, now included in the "most-in-demand" ornamental plants used for landscape design. There is a relatively small difference in terms of the measurement range of the essential parts. Furthermore, two easily observable characters are the leaf margin and the leaf apex. Most of the specimens collected from the wild exhibit an acute apex and a very slight revolute margin. Cultivated specimens have a more or less rounded apex and a more distinct revolute margin. The species is commonly regarded as $P$. polystachyus, however the revolute margin and some specimens have a more or less rounded apex which provides a boundary between the two species. The species is newly recorded in Palanan, Isabela Province and Palaui, Cagayan (Fig. 7).

Material examined:

LUZON. Batanes, Basco Reynoso \& Recio 165472 (PNH!), Ramos BS80397 (K!); Itbayat Island, Fernando 914 (LBC!), Madulid PPI2397325 (K!); Dalupiri Island, Bartlett 15138, 15192 (PNH!). Quezon Province, Pollilo Island, Burdeus, Larona 226 (LBC!). Isabela Province, Palanan, Ridsdale, Dejan, Baquiran ISU120 (CAHUP!). Cultivated: Laguna, Cajano 3075 (CAHUP!), Hernaez 40327 (CAHUP!); Manila, Claustro 116508, 116515, 4937 (PNH!).

6. Podocarpus rumphii Blume, Rumphia 3 (1847) 214; Miq., Fl. Ind. Bat. 2 (1859) 1073; Henkel \& Hochstetter, Syn. Nadelh. (1865) 393; De Boer, Conif. Arch. Ind. (1866) 15; Parl. in DC., Prodr. 16, 2 (1868) 515; Becc., Malesia 1 (1877) 179; Eichler in Engler \& Prantl, Nat. Pflanzenfam. ed. 2, 1 (1887) 104; Warb., Monsunia 1 (1900) 192; Pilger in Engler, Pflanzenr. IV, 5, Heft 18 (1903) 81; Foxw., Philipp. J. Sci. C 2 (1907) Bot. 258; Merr., Interpr. Rumph. (1917) 75; Foxw., Philipp. J. Sci. C 6 (1911) Bot. 164; Wasscher, Blumea 4 (1941) 432; N.E. Gray, J. Arnold Arbor. 39 (1958) 455; Gaussen, Gymn. Act. \& Foss. tome 2, fasc. 14, ch. 21 (1976) 179, t. 815; De Laub., Blumea 24 (1978) 496; De Laub. Kalikasan 7 (1978) 141; Fl. Males., Ser. 1, Spermat. 10 (1988) 415. Nageia rumphii (Blume) F. Mueller, Descr. Not. 1 (1877) 93. Margbensonia rumphii (Blume) A.V. Bobrov \& Melikyan, Byull. Moskovsk. Obshch. Isp. Prir., Otd. Biol. 103,1 (1998) 60. TYPE: Indonesia, New Guinea, Irian Jaya, Nov. Guinea, s.n.[L0050855].

Podocarpus philippinensis Foxworthy, Philipp. Jour. Sci. C 6 (1911) Bot. 163, t. 30; N.E. Gray, J. Arnold Arbor. 39 (1958) 434; Gaussen, Gymn. Act. \& Foss. tome 2, fasc. 14, ch. 21 (1976) 159. TYPE: Philippines, 1908, Foxworthy 5174 (US, NY, P, isotype) 
A medium to large tree up to 40-45 $\mathrm{m}$ tall and 40-75 $\mathrm{cm}$ dbh. Foliage buds $3-4 \mathrm{~mm}$ long and $2 \mathrm{~mm}$ in diameter, with triangular scales not spreading, however tips bending outward. Leaves linear, slender, acute to slightly acuminate; varying in size, leaves from saplings larger, 19-28.5 cm long and 20-26 mm wide; adult leaves, 8-23 cm long and 8-12 $\mathrm{mm}$ wide; shaded leaves, 10-20 $\mathrm{cm}$ long and 8-17 $\mathrm{mm}$ wide; exposed leaves, 10.5-14 cm long and 10-12 mm wide; upper midvein distinguished by broad low ridge $0.5-1 \mathrm{~mm}$, indistinct and more or less prominent below, tapered abruptly at the base to a 3-14 mm petiole. Male cones sessile, slender, in clusters of at least five and as many as eight, $3-4.5 \mathrm{~cm}$ long and $2-4 \mathrm{~mm}$ in diameter, including small sterile scales forming a cluster, microsporophyll apex with rounded projections, usually crowded. Foliola 1.5-2 mm long. Seed-bearing structure on a peduncle 7-13 $\mathrm{mm}$ long; receptacle with fertile bract $10-12 \mathrm{~mm}$ long and two shorter sterile bracts, the second $7-8 \mathrm{~mm}$ and the third $6 \mathrm{~mm}$; seed ovoid, including its covering 11-15 mm long and 10-12 $\mathrm{mm}$ in diameter, tapered at the base to a wedge, 0.9-1 mm long.

Etymology This species was named in honour of George Eberhard Rumphius (1628-1702), author of an early Flora of Ambon.

Together with $P$. neriifolius, this species is widely distributed in the Philippines and nearby regions. The long and narrow leaves are easily observable characters of this species even at maturity. Additional examined specimens revealed a wider range of leaf measurements from specimens collected from different areas. New distribution areas of the species include San Miguel, Bulacan, Makiling National Park in Laguna, Infanta in Quezon, Mt Halcon in Mindoro, Raja Sikatuna Forest Reserve in Bohol, Mt Apo Range (Davao Side), a geothermal power plant site in Kidapawan, Mt Kitanglad Range in Bukidnon, NALCO, Tungao in Agusan del Norte and Mt Hamiguitan in Davao Oriental.

Material examined:

LUZON. Pampanga, Mt Arayat, Merrill 3917 (K!), Curran PFB17664 (P!, NY!, US!, K!); Bataan, Limay Peak, Foxworthy \& Whitford 5174 (NY!, US!, K! isotypes of Podocarpus philippinensis); Bulacan, San Miguel Lagrimas \& Rojo 83845 (PNH!, PUH!); Laguna, Makiling National Park, Tiangco 83536 (PNH!), 5028 (PUH!), Martinez 6771 (PUH!), 6739 (PUH!), Gomez 6762 (PUH!), Banaag 6762 (PUH!), Quedado 6733 (PUH!), Macalos 4935 (PUH!), Naruso 18378 (CAHUP!), Hilario 18379 (CAHUP!), Hernaez 3563, 35108 (CAHUP!), Fernando 073, 044 (CAHUP!); Mindoro, Mt Halcon, Mandia 544 (K); Quezon, Infanta, Lagrimas 5143 (PUH!). MINDANAO. Kidapawan, Mt Apo Geothermal Project Site, Co 3699 (CAHUP!); Agusan del Norte, Tungao Rojo $121542 \& 121543$ (PNH!).

7. Podocarpus palawanensis de Laub. \& Silba, Phytologia 64, 4 (1988) 291. TYPE: LUZON. Palawan, Taytay, Sitio Ibangley, Ridsdale 1502 (L, holotype; K, isotype)

A small to medium-sized tree up to $7 \mathrm{~m}$ tall. Bark fissured. Foliage buds small, 4-6 $\mathrm{mm}$ long and 4-5 $\mathrm{mm}$ in diameter, globular, with triangular scales spreading mostly at the apex. Leaves linear to linear lanceolate, thick, $10.5-18.4 \mathrm{~cm}$ long by $8-11 \mathrm{~mm}$ wide, 
tapering at both ends, apex narrowly acute; upper midvein raised, sharp and narrow, tapered at the base to a 5-7 mm petiole. Male cones pedunculate, $3.5-4.5 \mathrm{~cm}$ long by 6.5-8 mm diameter, solitary, strobili moderately flat, microsporophyll apex lanceolate, about $4 \mathrm{~mm}$ long. Seed-bearing structure not seen.

Etymology The species is named after Palawan, the place where it was first collected and is known to be endemic.

De Laubenfels \& Silba (1988) established unique characters which do not support the placement of this species in synonymy of any other species. These characters are included in the description. Furthermore, these characters are also used in this study to place this species in section Macrostachyus. This is due to the globular foliage buds with triangular scales, leaves linear to linear-lanceolate, with acute apex and narrowing at the base and lanceolate apex of the microsporophylls. It is also noteworthy that there are no records of the occurrence of $P$. rumphii in Palawan (Fig. 10). The female cone has not yet been seen and described which indicates that there is a need to collect female specimens.

Material examined:

LUZON. Palawan, Taytay, Sitio Ibangley, Ridsdale 1502 (L!, K!, isotype)

8. Podocarpus neriifolius D.Don, Gen. Pinus ed. 1 (1824) 21; Prod. Fl. Nep. (1825) 55; Spreng. Syst. Veg. 3 (1826) 889; Bennett in Bennett \& R.Br. Pl. Jav. Rar.1 (1838) 40; Endl., Syn. Conif. (1847) 215; Parl., Bot. Mag. 78 (1852) t. 4655; Henkel \& W.Hochst., Syn. Nadelh.(1865) 381; Parl. in DC., Prodr. 16, 2 (1868) 514; Eichler in Engler \& Prantl, Nat. Pflanzenfam. ed. 2, 1 (1887) 104; Hook.f., Fl. Brit. India 5 (1888) 649; Stapf, Trans. Linn. Soc. II, Bot. 4 (1894) 249; Warb., Monsunia 1 (1900) 193; Pilger in Engler, Pflanzenr. IV, 5, Heft 18 (1903) 80; Koorders \& Valeton, Bijdr. 10 (1904) 265; Merrill, Philipp. J. Sci. C 1 (1906) Suppl. 24; Foxw. Philipp. J. Sci. C 2 (1907) Bot. 258; Gibbs, J. Linn. Soc., Bot. 39 (1909) 183; Foxw., Philipp. J. Sci. 6 (1911) Bot 162; Ridley, J. Straits Br. Roy. Asiat. Soc. 60 (1911) 57; Koord., Exk. Fl. Jav. 1 (1911) 65, f. 3; Gibbs, Ann. Bot. o.s. 26 (1912) 549, t. 51, f. 48-51, t. 53, f. 78; Koord., Atlas 2 (1915) t. 589; Fl. Tjibodas 1 (1922) 3; Ridley, Fl. Malay Penins. 5 (1925) 281; Pilger in Engler \& Prantl, Nat. Pflanzenfam. ed. 2, 13 (1926) 247; Hickel, Fl. Indo-Chine 5 (1931) 1069; Wasscher, Blumea 4 (1941) 437, incl. var. polyantha Wasscher, l.c. 455; Gray, J. Arnold Arbor. 39 (1958) 460, 467; Backer \& Bakh.f., Fl. Java 1 (1963) 90; Gaussen, Gymn. Act. \& Foss. tome 2, fasc. 14, ch. 21 (1976) 187, f. 805; De Laub., Kalikasan 7 (1978) 139; Fl. Males. 10 (1988) 400; De Laub., Novon, 24 (2015) 136. Nageia neriifolia (D.Don) Kuntze, Rev. Gen. Pl. 2 (1891) 800. Margbensonia neriifolia A.V. Bobrov \& Melikyan, Byull. Moskovsk. Obshch. Isp. Prir., Otd. Biol. 103,1 (1998) 60. TYPE: Nepal. Bagmati: Sangkoo, 1821, Wallich Catalogue, no. 6052A (BM, lectotype designated by Farjon, 2010: 868; B, K-W, NY, P, isolectotypes).

A medium to large tree up to $45 \mathrm{~m}$ tall and $8-100 \mathrm{~cm}$ dbh. Foliage buds $2-7 \mathrm{~mm}$ long and 2-4 $\mathrm{mm}$ in diameter, with spreading scales mostly triangular. Leaves linear to linear lanceolate, acute apex; varying in size, leaves from saplings longer, up to $20 \mathrm{~cm}$ long and 15-19 mm wide, acuminate or acute; adult leaves 5-12 cm long and 8-13 mm 
wide, linear; shaded leaves $8-16 \mathrm{~cm}$ long and $12-15 \mathrm{~mm}$ wide, apex slightly acuminate; exposed leaves 12-15 cm long and 10-15 mm wide, linear-lanceolate, broadly acute; upper midvein distinguished by abruptly raised rib $0.5-0.8 \mathrm{~mm}$ with perpendicular sides and rounded top and broadly and less distinct below, abruptly tapered at the base to a 6-10 mm petiole. Male cones commonly in clusters of three, sessile, $2.5-4 \mathrm{~cm}$ long and 2.5-3.5 mm in diameter, with sterile scales at the base, microsporophyll apex triangular. Foliola 1.5-2 mm long. Seed-bearing structure on a peduncle $8-10 \mathrm{~cm}$ long; receptacle with fertile bract 6-9 mm long and shorter sterile bract, sometimes both are fertile; seed globose, including its covering 10-12 $\mathrm{mm}$ long and 5-7 $\mathrm{mm}$ in diameter, without a crest.

Etymology The specific epithet refers to the leaves which resemble those of oleander (Nerium) in shape (Greek, nerion oleander; Latin, folium leaf).

De Laubenfels (2015) added two new species in the Philippines, namely Podocarpus neglectus and Podocarpus hookeri. These two species were previously treated as synonyms of $P$. neriifolius. This paper recognises $P$. neglectus and $P$. hookeri as distinct species which do not occur in the Philippines. The materials determined by de Laubenfels (2015) to P. neglectus are P. polystachyus. One of the distinct characteristics used in describing $P$. neglectus is the acute apices of the leaves. Careful examination of these materials reveals that their leaves have acute to rounded leaf apices and are narrowed at the base which resembles $P$. polystachyus. Thus, $P$. neglectus is not part of the Philippine species of Podocarpus.

Also, this paper does not recognise Podocarpus hookeri as a species found in the Philippines. In the work of de Laubenfels (2015), some collections previously referred to as $P$. neriifolius are cited as $P$. hookeri. Some materials from Merritt 6790, Merrill 1992 and Loher 12785 were examined and these materials are treated under P. neriifolius in this paper. These materials were included under $P$. hookeri due to linear and broader leaves, and acuminate to broad apices (de Laubenfels, 2015). These features are among the variations that exist within the species due to difference in location and life stages. Also, these materials closely resemble one collection by Tabat 19914 at US which is also named $P$. neriifolius. Moreover, one collection from Merrill 5615, treated under $P$. hookeri by de Laubenfels (2015), closely resembles P. pilgeri and is treated as such in this paper.

This species is widely distributed in the Philippines and nearby regions. It is regarded as of least concern, in terms of conservation priority, even though there are increasing reports of over-exploitation of the species for timber. Additional specimens revealed a new measurement range of the essential parts, particularly the leaves in their mature and juvenile stages. New distribution records include Mt Malindang in Misamis Oriental, Samar and Lantapan in Bukidnon (Fig. 12).

Material examined:

LUZON. Rizal, Montalban, Loher 12785 (A!, P!); Quezon Province, Polillo Island, McGregor 10779 (NY, non vidi), Tayabas, Pagbilao, Merrill 1992 (K!, US!); Mindoro, Mt Halcon, Ridsdale, Coode \& Reynoso 164764 (PNH!), Sulit 10076 (PUH!, PNH!), Mandia 544 (K!), Merritt 6790 (US!); Palawan, Bato, Tabat 19914 (US!). MINDANAO. 
Bukidnon, Malaybalay, Madulid 108747 (PNH!), Mt Kitanglad, Gaerlan PPI3264 (K!); Agusan Province, Upper Uhat Nalco, Rojo 1569 (CLP!).

9. Podocarpus macrocarpus de Laub., Kalikasan 7(2) (1978) Bot. 140; Fl. Males., Ser. 1, Spermat. 10 (1988) 418. TYPE: Luzon, Benguet Prov., Curran 10894 (US, holotype, $\mathrm{K}, \mathrm{L}, \mathrm{NY}$, isotypes)

A small to medium-sized tree up to $20 \mathrm{~m}$ tall and $20-30 \mathrm{~cm}$ dbh. Foliage buds 2-5 $\mathrm{mm}$ long and 2-4 $\mathrm{mm}$ in diameter, with triangular to rounded scales spreading. Leaves linear to linear lanceolate, acute, sometimes slightly rounded; varies in size, leaves from saplings larger, 8-14 cm long and 10-14 mm wide, linear-lanceolate, acute; adult leaves, 7-10 cm long and 7-13 mm wide; exposed leaves, 6-11 cm long and 5-10 mm wide, more or less linear; upper midvein distinguished by rib with sloping sides $0.4-0.7 \mathrm{~mm}$ and broadly and less distinct below, tapered gradually at the base to a 1-5 $\mathrm{mm}$ petiole. Male cones sessile, cylindrical, in clusters of at least four, 2-2.5 cm long and $4-5 \mathrm{~mm}$ in diameter, including small sterile scales forming a cluster, microsporophyll apex triangular. Foliola, 1.5-2 mm long. Seed structure in a peduncle, 5-12 mm long; receptacle with fertile bract $8.5-12 \mathrm{~mm}$ long and shorter sterile bracts; seed globular with its covering, 14-15 mm long and 10-13 $\mathrm{mm}$ in diameter, with a broad stalk, 2-2.5 mm, at the base.

Etymology The specific epithet refers to the large seeds (Greek macro = large; Greek carpos $=$ fruit) produced by this species.

The distribution of this species is more localised in northern Luzon, however there are specimens collected from Zambales and Quezon Province (Mt Binuang) (Fig. 15). Specimens collected from the periphery of Mt Kitanglad are determined as P. macrocarpus. These specimens are taken from individuals occurring at an altitude of $1,200-1,700 \mathrm{~m}$. Their identification is uncertain due to the wide discrepancy of the common distributional and altitudinal range. It is most likely $P$. rumphii due to its longer leaves and abruptly tapered base. In this work, the species is grouped together with $P$. polystachyus based on the clustering of the male cones which is different in de Laubenfels's 1978 assessment of Philippine Coniferae and Taxaceae.

Material examined:

LUZON. Ilocos Norte, Mt Pico de Loro, Edaño 5176 (PNH!, L!); Mt Province, Botoc, Mt Polis, Mendoza 20388 (PNH!); Benguet, Curran 10826 (US!), 10894 (US!, K!, L!), Sto. Tomas, Pancho 3010 (CAHUP!), de Laubenfels P658 (CAHUP!, P!), P659 (CAHUP!, L!), P651 (CAHUP!, L!), P721 (CAHUP! L!), P722 (CAHUP!, L!); Zambales, Sta. Cruz, Guisguis, Lomibao 1153 (CLP!); Quezon Province, Mt Binuang, Ramos \& Edaño BS 28635 (K!).

10. Podocarpus polystachyus R.Br. ex Endl., Syn. Conif. (1847) 215; Miq. Fl. Ind. Bat. 2 (1859) 1072; Henkel \& Hochstetter, Syn. Nadelh. (1865) 392; Parl. in DC., Prodr. 16, 2 (1868) 515; Warb., Monsunia 1 (1900) 192; Pilger in Engler, Pflanzenr. IV, 5, Heft 18 (1903) 79; Merrill, Philipp. J. Sci. C 3 (1908) Bot. 394; Foxw., Philipp. J. Sci. C 6 (1911) 
Bot. 161; Ridley, Fl. Malay Penins. 5 (1925) 282, t. 288; Wasscher, Blumea 4 (1941) 456, t. 5, f. 14a-c; N.E. Gray, J. Arnold Arbor. 39 (1958) 469, f. 4; Keng in Whitmore, Tree Fl. Malaya 1 (1972) 49, f. 3, p.p.; Gaussen, Gymn. Act. \& Foss. tome 2, fasc.14, ch. 21 (1976) 21, p.p.; De Laub., Kalikasan 7 (1978) 142; Fl. Males., Ser. 1, Spermat. 10 (1988) 417. Nageia polystachya (R.Br. ex Endl.) Kuntze, Revis. Gen. Pl. 2 (1891) 800. Margbensonia polystachya (R.Br. ex Endl.) A.V.Bobrov \& Melikyan, Byull. Moskovsk. Obshch. Isp. Prir., Otd. Biol. 103, 1 (1998) 60. TYPE: Indonesia, 1875, Teijsmann 11385 (L, holotype).

A small to medium-sized tree up to $20 \mathrm{~m}$ tall and $45 \mathrm{~cm}$ dbh. Foliage buds $1.5-3 \mathrm{~mm}$ long and $2 \mathrm{~mm}$ in diameter with lanceolate spreading scales. Leaves linear to linearlanceolate, acute to slightly rounded, sometimes apiculate; varying in size, leaves from saplings larger, 5-10 cm long and 4-8 mm wide, linear-lanceolate, almost apiculate; adult leaves 3-9 cm long and 4-10 mm wide; exposed leaves 3-11 cm long and 3-7 mm wide; upper midvein distinguished by prominent rib with sloping sides $0.4-1$ $\mathrm{mm}$ and broadly and less distinct below, tapered gradually at the base to a $1.5-4 \mathrm{~mm}$ petiole. Male cones sessile, cylindrical, usually in clusters of five, 2-4 cm long and 2.5-3 cm in diameter, including small sterile scales forming a cluster, microsporophyll apex triangular. Foliola 1-1.5 mm long. Seed-bearing structure on a peduncle 3-7 $\mathrm{mm}$ long; receptacle with fertile bract 6-9 $\mathrm{mm}$ long and shorter sterile bracts; seed globular including its covering $8 \mathrm{~mm}$ long and $4-5 \mathrm{~mm}$ in diameter, with a small crest.

Etymology The specific epithet refers to the cluster of spikes or male cones.

This species, like $P$. costalis, occurs near coastal bluffs. Its occurrence, however, extends up to 1,000 $\mathrm{m}$ in karst limestone areas (Fig. 15). A specimen from Casiguran, Aurora is a new distribution record. Individuals are found in closed forest near coastal areas. The species also occurs in Benguet based on the collection of Sulit 7774 and Jacob 7591 and Subaan, San Teodoro, Mindoro based on Coode \& Ridsdale 5533. One collection from Tayabas Province, Quieb 27325, named Podocarpus neriifolius and deposited in US is $P$. polystachyus.

Material examined:

LUZON. Batanes, Basco, Quisombing, del Rosario, Gutierrez 79285 (PNH!); Ilocos Norte, Burgos, Ramos 27146 (L!, US!, P!); Benguet, Mt Tabayoc, Jacob 7591 (K!), Mt Nangaoto, Sulit 7774 (PNH!); Tayabas, Guinayangan, Escritor 20771 (K!, P!, US!); Quezon, Atimonan, Quezon National Park, Alvarez \& Saprid 77678 (CAHUP!), Medina, 021, 023 (CAHUP!), Hilupuwan, Pancho \& Liwag 16652 (CAHUP!), Tayabas, Quieb 27325 (US!); Mindoro, San Teodoro, Subaan Coode \& Ridsdale 5533 (PNH!), Ridsdale, Coode, Reynoso 164762 (PNH!); Palawan, Curran 3854 (BO!, K!, L!, P!, US!), Arborlan, Panacan, Sulit 12392 (PNH!), Puerto Princesa, Velasco 3532, 1011 (CAHUP!), Mt Victoria, Dransfield SMHI1274 (K!), Olympic Mines, Stone et al. PPI184 (L!, K!); MINDANAO. Surigao, Siargao Is. Stone et al. PPI12007 (L!), Bucas Is. Merrill 5268 (US!). 

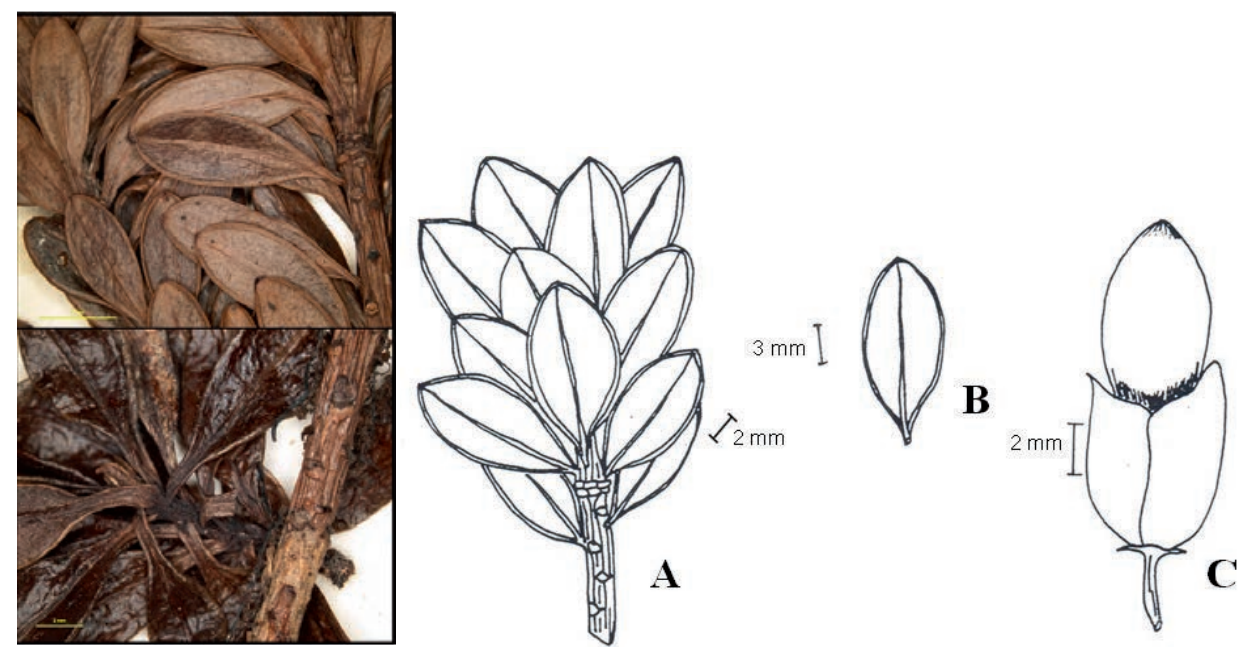

Fig. 1 Podocarpus glaucus Foxw. Left: Close-ups of leaves. Photos: Ingrid Lin, US (Merrill 5672). Right: A Sketch of the terminal shoot (Merrill 5672, K). B Leaf structure. C Seed-bearing structure (Cajano \& Realista 62516, CAHUP).
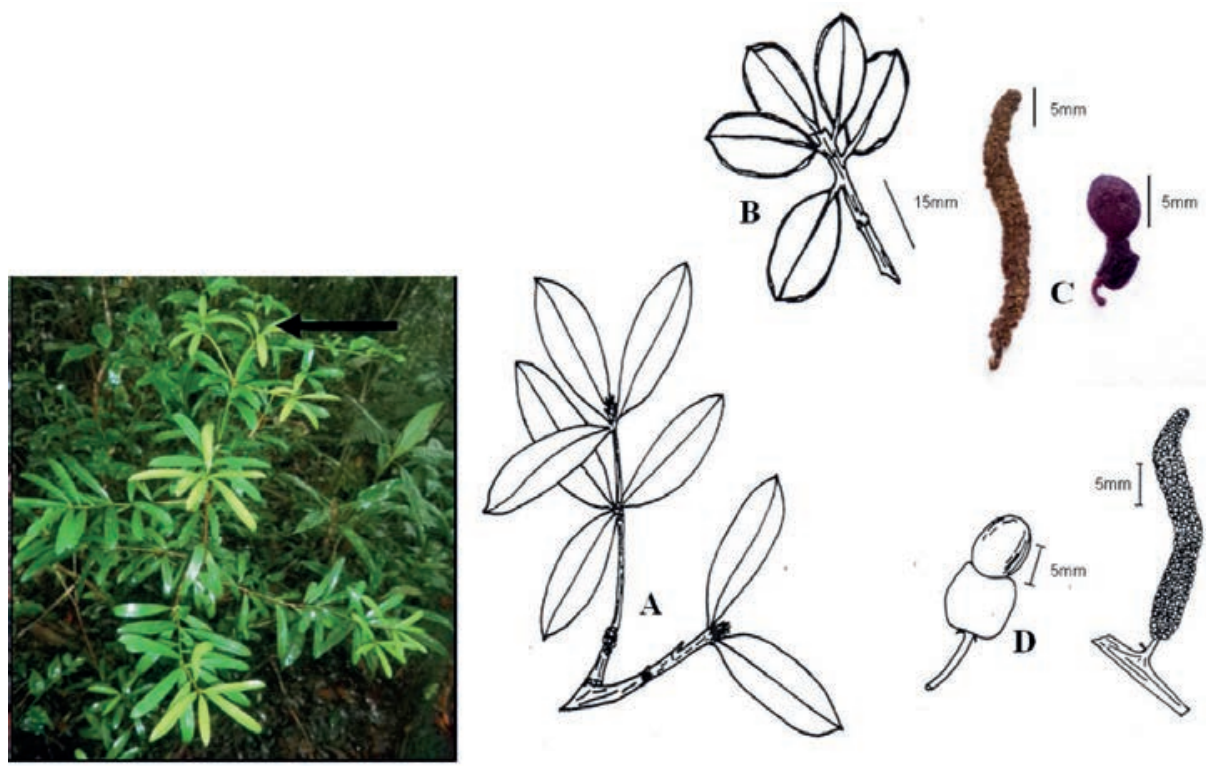

Fig. 2 Podocarpus ramosii R.R.Mill. Left: Sapling from Mt Banahaw, Quezon Province. Photos: F.R.P. Salvaña. Right: A Sketch of terminal shoot of juvenile plant (Fernando 055 CAHUP). B Sketch of terminal shoot of mature plant (Gruezo 5764 CAHUP). C Reproductive structures. D Seed-bearing structure (Hernaez 3518 CAHUP). E Male cone (de Laubenfels P663 CAHUP). 

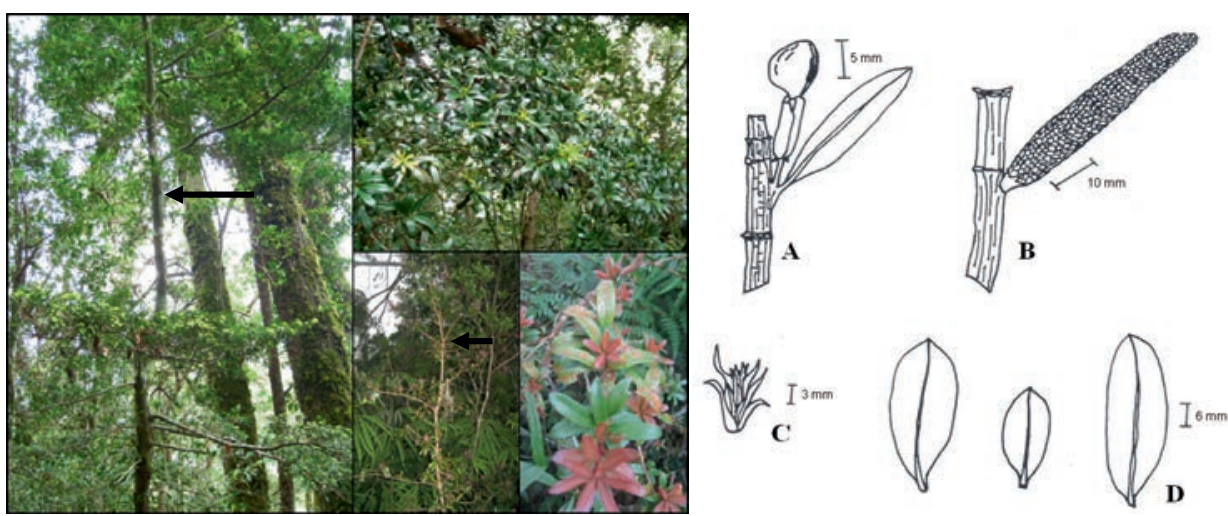

Fig. 3 Podocarpus pilgeri Foxw: Left: Habit (arrow, left photo) and saplings showing juvenile leaves flushing red. Photos: F.R.P. Salvaña. Right: A Shoot with seed-bearing structure (Sulit 10056, PNH). B Male cone (Hutchinson 4673, K). C Foliage bud (Edaño 4921, PUH). D Variation in leaf form (Edaño 22015, PNH; Madulid et al. 3149, K; Cajano \& Hernaez 60617, CAHUP).

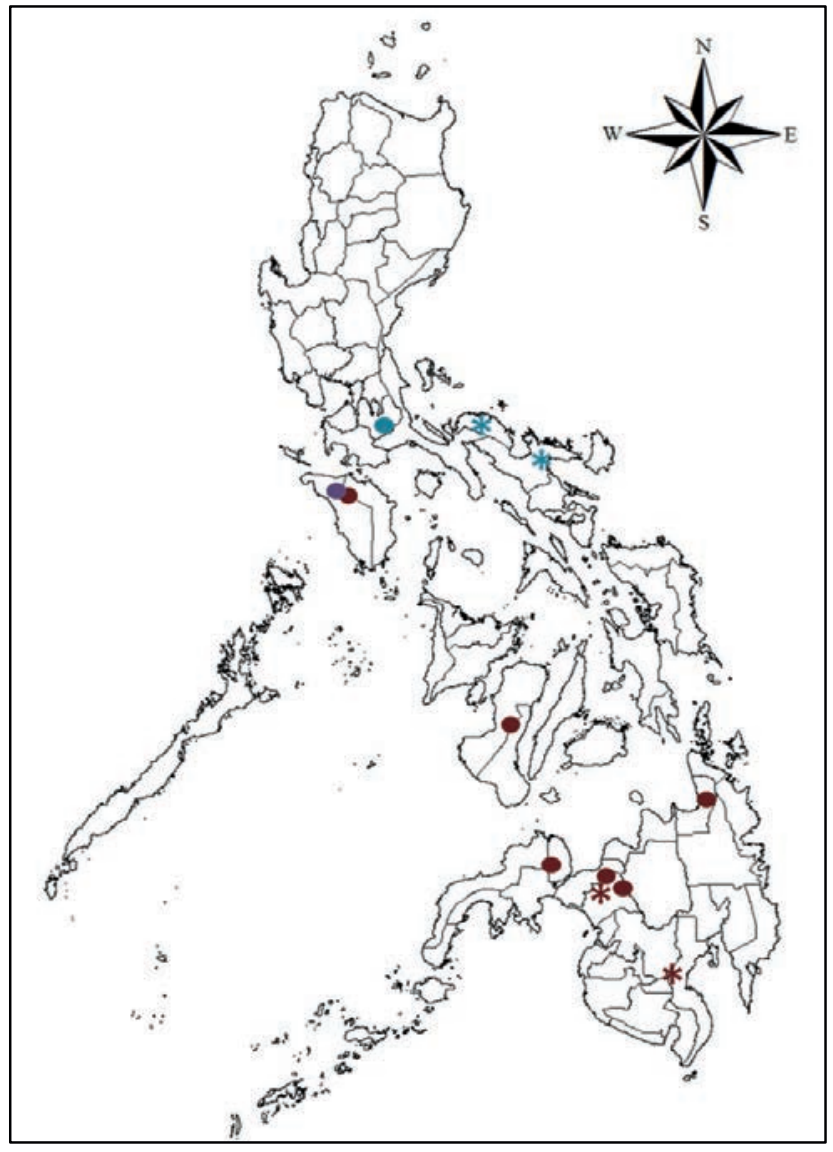

Fig. 4 Distribution map of Podocarpus glaucus Foxw. (๑); Podocarpus ramosii R.R.Mill (๑); and Podocarpus pilgeri Foxw. (•) (* indicates new distribution areas). 


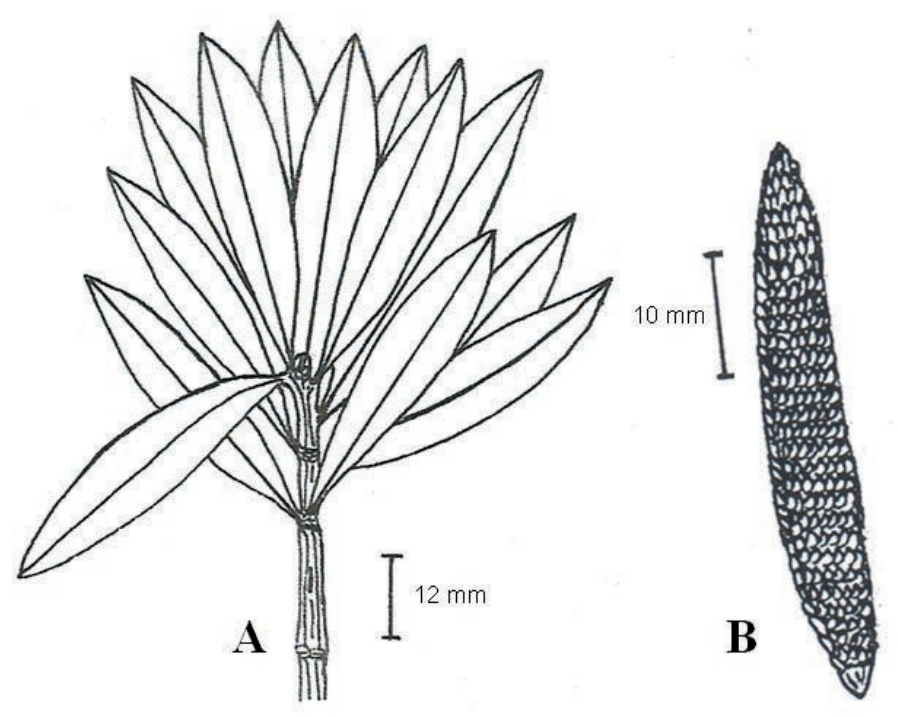

Fig. 5 Podocarpus lophatus de Laub.: A Terminal shoot (Ferreras 16663, PUH). B Male cone. C Detached seeds (Curran \& Merritt 9511, K).

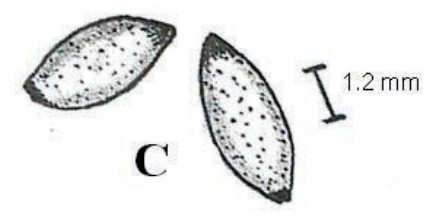

Fig. 6 Podocarpus costalis C. Presl: A Terminal shoot (Larona 226, LBC). B Leaf. C Male and female reproductive structures. $\mathrm{D}$ Male cone (Hernaez 40327, CAHUP). E Seed-bearing structure (Bartlett 15138, $\mathrm{PNH}$ ).

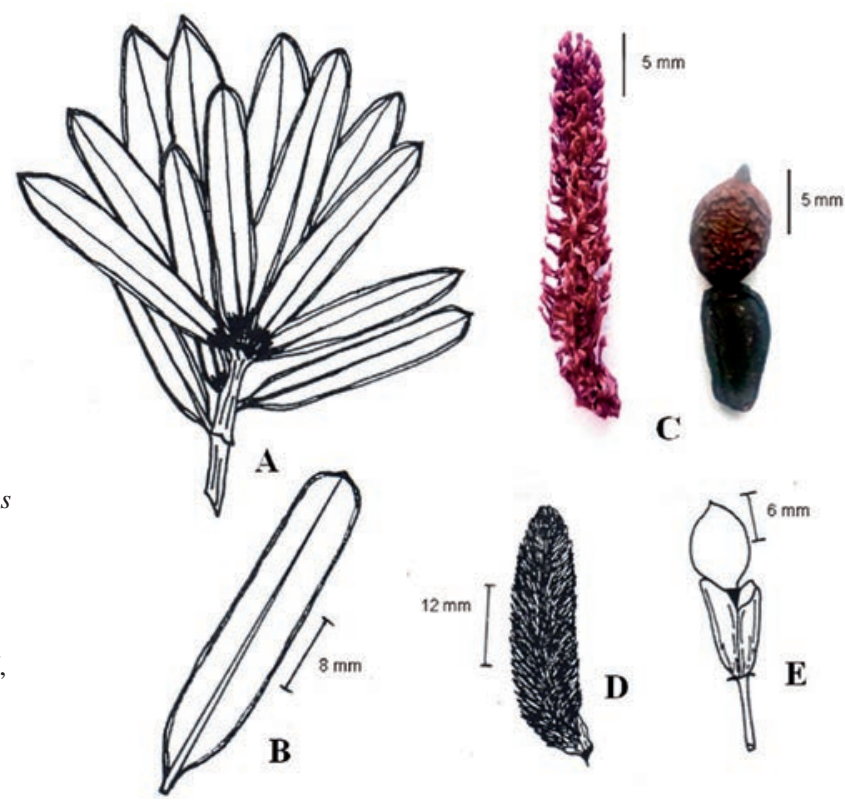




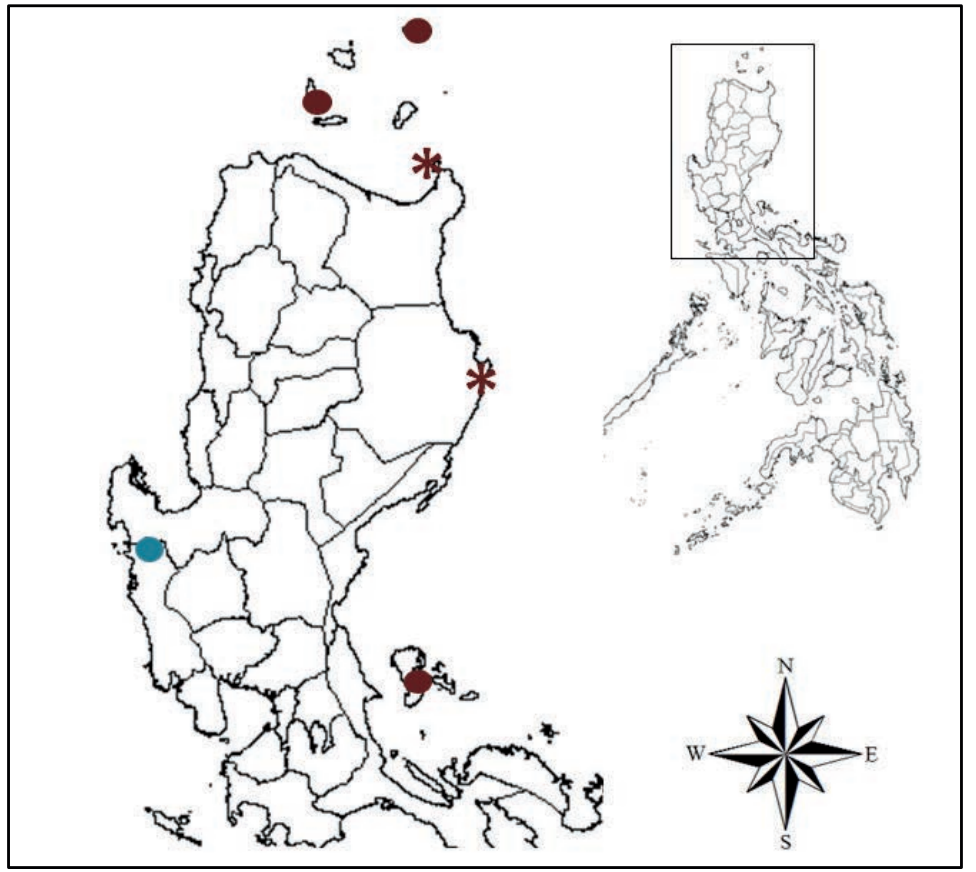

Fig. 7 Distribution map of Podocarpus lophatus de Laub. (๑); and Podocarpus costalis C. Presl. (•) (* indicates new distribution areas).
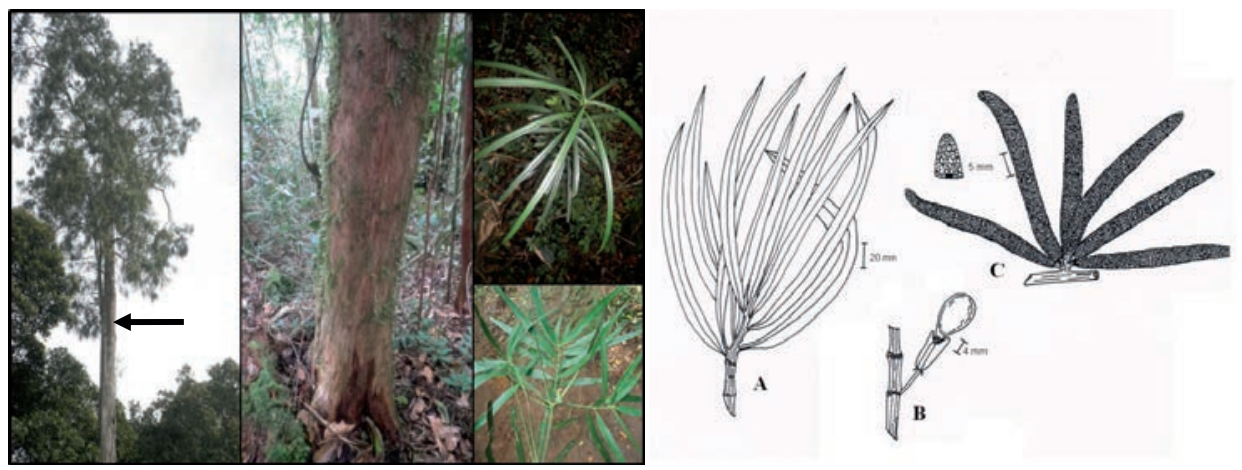

Fig. 8 Podocarpus rumphii B1.: Left: Habit, sapling and fertile branch with seed-bearing structure. Photos: F.R.P. Salvaña. Right: A Terminal shoot (Banaag 6762, PUH). B Seed-bearing structure (Rojo 121542, PNH). C Cluster of male cones (Curran 17664, K) and (inset top left) apex of male cone enlarged. 
Fig. 9 Podocarpus palawanensis Silba \& de Laub.: A Terminal shoot. B Leaf. C Male cones. D Foliage buds. All drawn from Ridsdale 1502 (L).

Fig. 10 Distribution map of Podocarpus rumphii BI. (•) and Podocarpus palawanensis Silba \& de Laub. (๑) (* indicates new distribution areas).
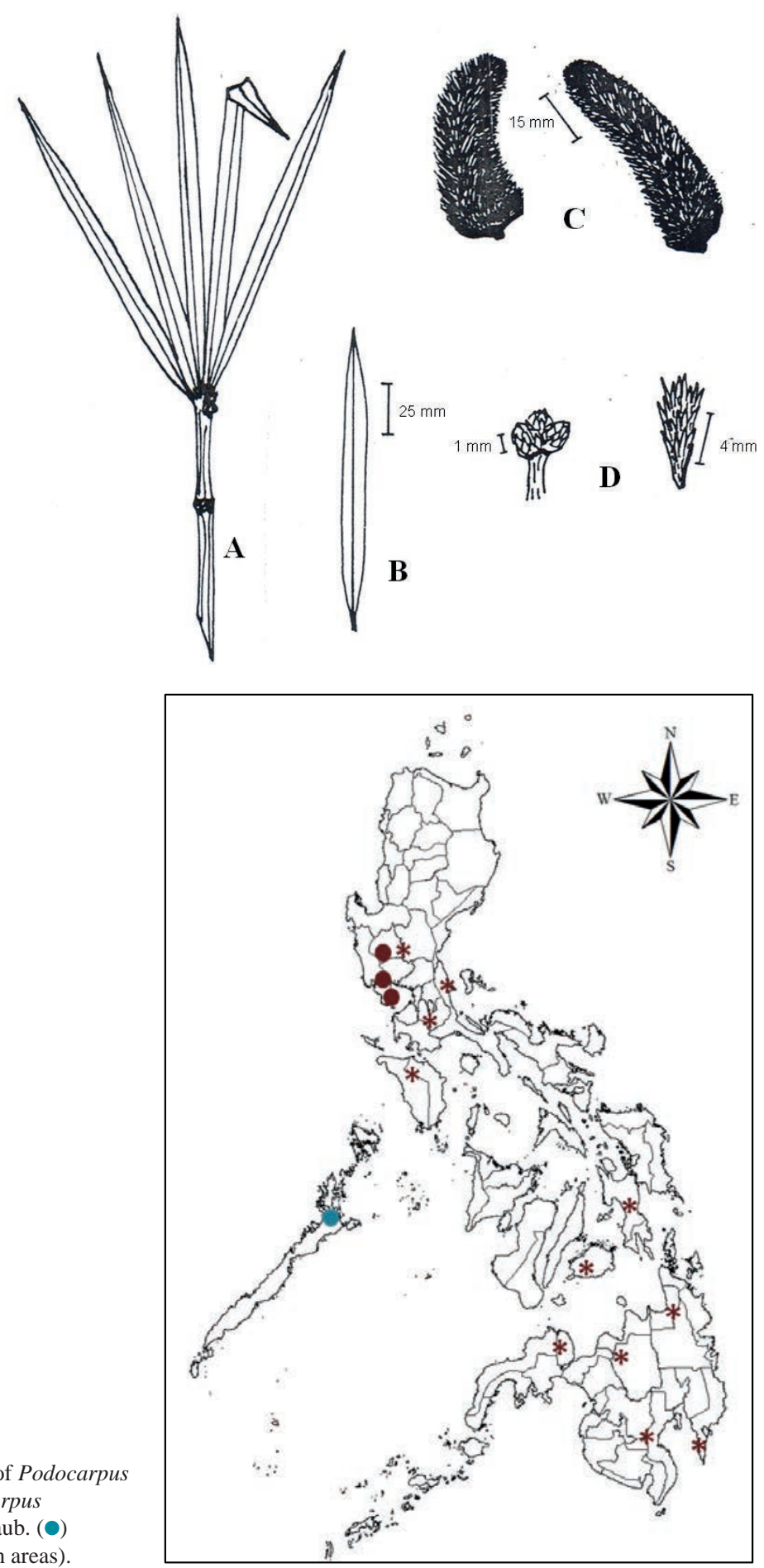

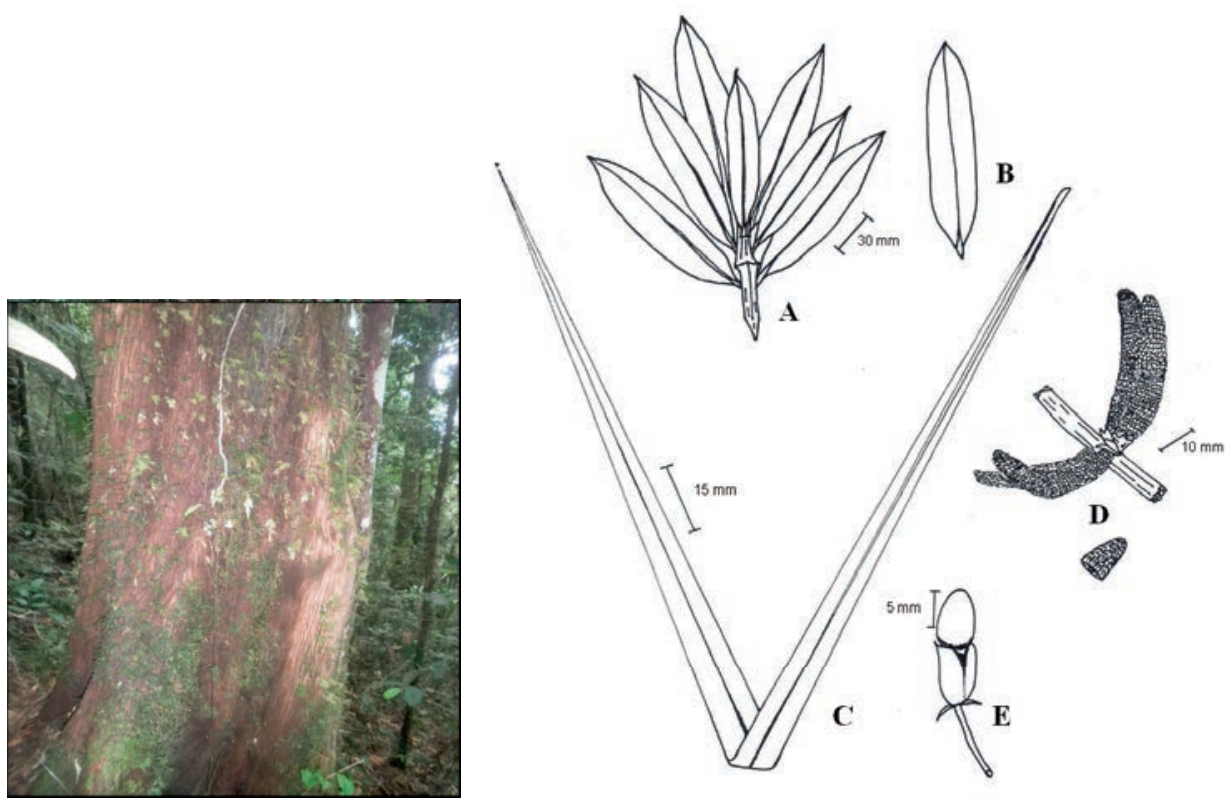

Fig. 11 Podocarpus neriifolius D.Don: Left: Habit. Photo: F.R.P. Salvaña. Right: A \& B Terminal shoot of mature leaves (Madulid 108747, PNH). C Juvenile leaf. D Male cones (Merrill 1992, K). E Seed-bearing structure (Sulit 10076, PNH).

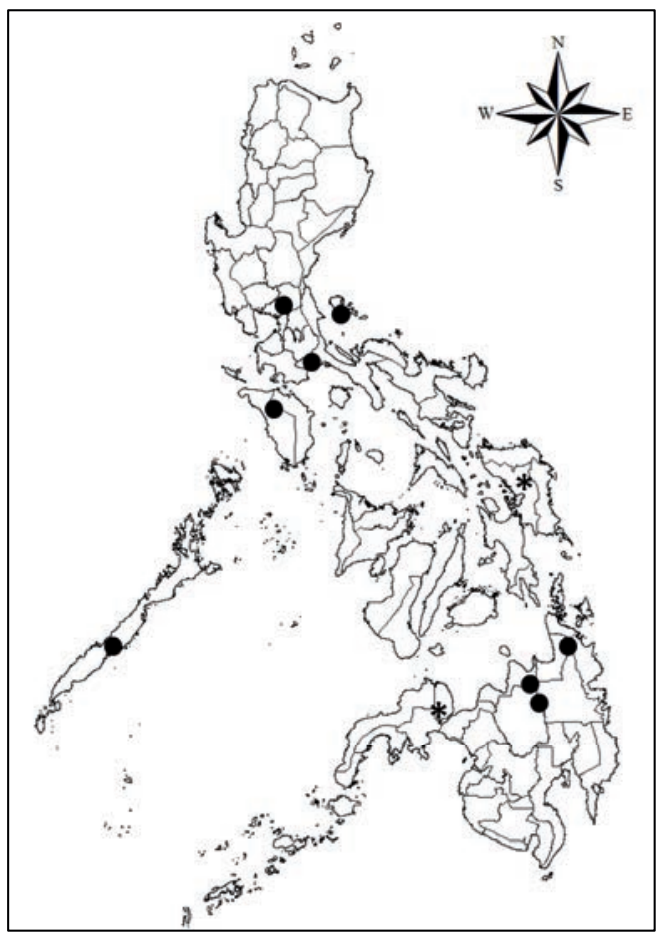

Fig. 12 Distribution map of Podocarpus neriifolius D. Don (* indicates new distribution areas). 

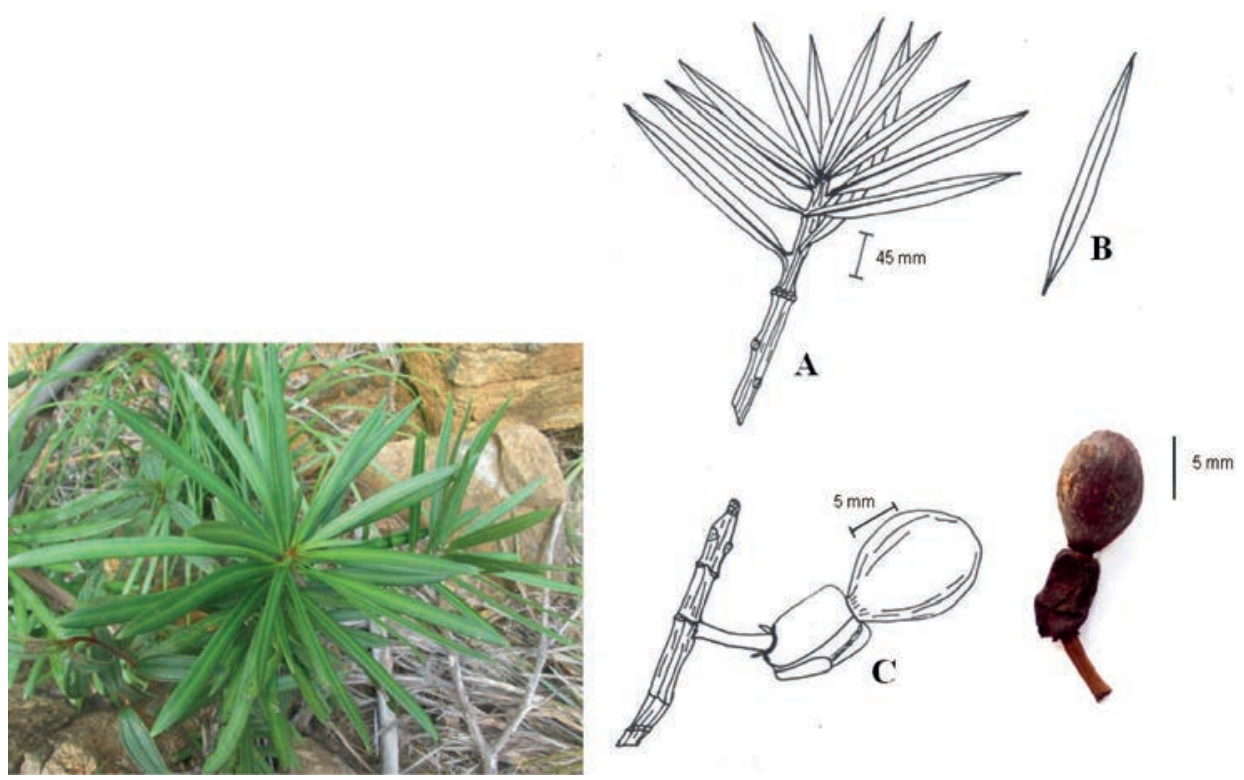

Fig. 13 Podocarpus macrocarpus de Laub.: Left: Sapling. Photos: F.R.P. Salvaña. Right: A Terminal shoot (Pancho 3010, CAHUP). B Leaf. C Seed-bearing structure (de Laubenfels P658, CAHUP).
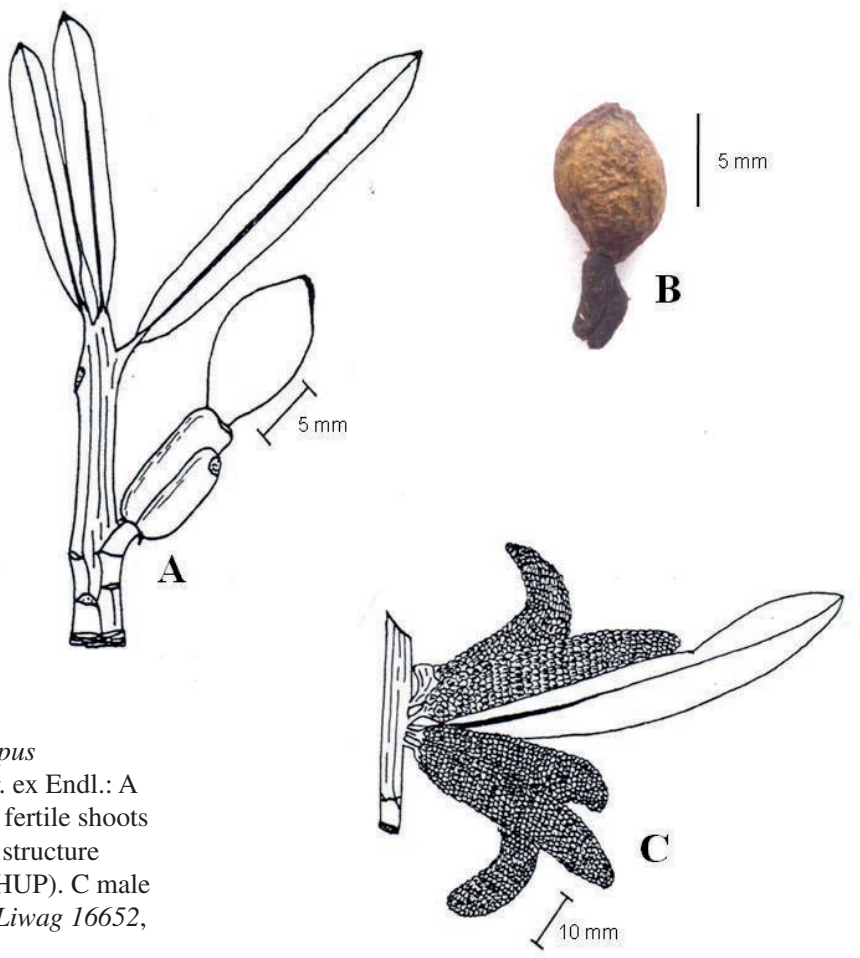

Fig. 14 Podocarpus polystachyus R.Br. ex Endl.: A \& B Sketch of the fertile shoots with seed-bearing structure (Medina 021, CAHUP). C male cones (Pancho \& Liwag 16652, CAHUP).

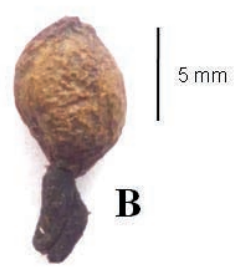




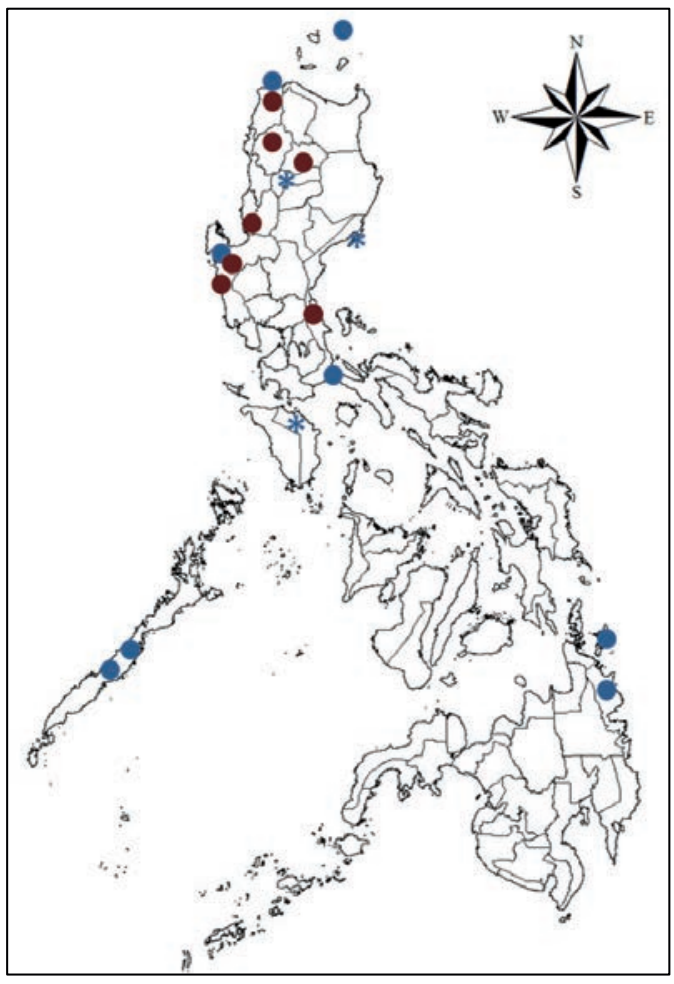

Fig. 15 Distribution map of Podocarpus macrocarpus de Laub. (•); and Podocarpus polystachyus R.Br. ex Endl. (๑) (* indicates new distribution areas).

\section{CONCLUSION AND RECOMMENDATIONS}

The taxonomy of Podocarpus in the Philippines has undergone few reviews, as reflected in the small number of taxonomic works that focus on this group. Presented here is a complete description of a wider range of characters, clarification of the overlapping characters within and between species, and the determination of some variable forms of species that provide a reliable taxonomic treatment of each Philippine Podocarpus species.

It is recommended that studies be carried out on the phylogenetic relationship of each species. This will further elucidate relationships between the Philippine species of Podocarpus. DNA sequencing work following that of Biffin et al. (2011) and Knopf et al. (2012) will hopefully provide clarification of species affinities and geographic cohesion. Based on altitudinal distribution of each species, studies of the inclusion of Podocarpus species in reforestation projects can also be assessed.

\section{ACKNOWLEDGEMENTS}

Special thanks to Eugene Lorence Logatoc and Ingrid Lin of the United States National Herbarium Smithsonian (US), and Pieter Pelser and Ronald Achacoso of www.phytoimages.siu.edu for photos; to Botanical Herbarium (CAHUP), Museum of 
Natural History, University of the Philippines Los Baños, College, Laguna; Philippine National Herbarium (PNH), National Museum, Manila and Jose Vera Santos Memorial Herbarium (PUH), Institute of Biology, University of the Philippines Diliman, Quezon City; and to DOST-ASTHRDP for the financial support.

\section{REFERENCES}

BIFFIN, E., CONRAN, J.G. \& LOWE, A.J. (2011). Podocarp evolution: a molecular phylogenetic perspective. In TURNER, B.J. \& CERNUSAK, L.A. (eds) Ecology of the Podocarpaceae in tropical forests (ed. by), pp. 1-20. Smithsonian Contributions to Botany, No. 95. Smithsonian Institution Scholarly Press, Washington, DC.

BOCHARNIKOVA, A.D. (1960). Atlas of Upper Cretaceous, Paleocene and Eocene SporePollen Complexes of several regions of the U.S.S.R. [in Russian]. Trans. All-Soviet Sci.Res. Inst. Minist. Geol. \& Petr. Conserv. U.S.S.R. n.s., 30. Leningrad. [Original not seen; facsimiles of new description by Bocharnikova (1960) are reproduced in Kremp et al., Cat. Fossil Spores Pollen, 16 (1962).]

DE LAUBENFELS, D.J. (1978). The taxonomy of Philippine Coniferae and Taxaceae. Philippine Journal of Biology, 7(2): 117-152.

DE LAUBENFELS, D.J. (1985). A taxonomic revision of the genus Podocarpus. Blumea 30: 251-278.

DE LAUBENFELS, D.J. (1988). Series 1 - Spermatophyta - Revisions - Coniferales. Flora Malesiana, 10(3): 395-419.

DE LAUBENFELS, D.J. (2015). New sections and species of Podocarpus based on the taxonomic status of P. neriifolius (Podocarpaceae) in Tropical Asia. Novon: A Journal for Botanical Nomenclature, 24(2): 133-152.

DE LAUBENFELS, D.J. \& SILBA, J. (1988). Notes on Asian-Pacific Podocarpaceae: 1 (Podocarpus). Phytologia, 64: 290-292.

FOXWORTHY, F.W. (1911). Philippine gymnosperms. Philippine Journal of Science, 6: 149-178.

GASCON, C.N., GARCIA, R.C., BELTRAN, F.N., FALLER, W.C. \& AGUDILLA, M.A.R. (2013). Biodiversity assessment of Mt Banahaw de Dolores, Philippines. Asian Journal of Biodiversity, 295: 23-45.

KNOPF, P., SCHULZ, C., LITTLE, D.P., STÜTZEL, T. \& STEVENSON, D.W. (2012). Relationships within Podocarpaceae based on DNA sequence, anatomical, morphological and biogeographical data. Cladistics, 28: 271-299.

MERRILL, E.D. (1923). An Enumeration of Philippine Flowering Plants. Philippine Bureau of Science, no. 18. Bureau of Printing, Manila.

MILL, R.R. (2002). Proposal to conserve Podocarpus rotundus de Laub. (recent Podocarpaceae) over Podocarpus rotundus Bocharn. (fossil Podocarpaceae). Taxon, 51:185-186.

MILL, R.R. (2006). A new name for Podocarpus rotundus de Laub. (Podocarpaceae). Edinburgh Journal of Botany, 63(1): 81-83. 